\title{
CHRYSTOLOGICZNA INTERPRETACJA KSIĘGI JOZUEGO U ORYGENESA
}

Kluczem do chrześcijańskiej interpretacji Księgi Jozuego w epoce patrystycznej jest typologia chrystologiczna. ${ }^{1}$ Pierwszy stosuje ją w sposób konsekwentny i całościowy do postaci Jozuego i motywów literackich księgi biblijnej noszącej jego imię aleksandryjski prezbiter, teolog i komentator Pisma Świętego, Orygenes. ${ }^{2}$

\section{Chrystologiczna symbolika imienia i misji Jozuego}

Pierwszym powodem skojarzenia postaci Jozuego z Jezusem jest samo brzmienie imienia. Septuaginta thumaczy hebrajskie imię głównego bohatera Księgi Jozuego Jehoszua przez greckie lesous, które jest tym samym imieniem, jakie nosił Zbawiciel. To thumaczenie głęboko uwarunkowało greckojęzyczną tradycję interpretacji Księgi Jozuego. W tradycji zachodniej starołacińskie przekłady Biblii wzorują się na Septuagincie i tłumaczą Jehoszua przez Jesus. Komentatorzy zaś, chcąc odróżnić Zbawiciela od następcy Mojżesza, zwykle piszą o tym ostatnim Jesus Nave (Jezus syn Nuna). Dopiero Hieronim $(† 419)$ wprowadza wraz z przekładem Wulgaty nowe tłumaczenie $J e$ hoszua jako Josue. ${ }^{3}$

1 Na temat typologii chrystologicznej w odniesieniu do postaci Jozuego, z perspektywy tradycji biblijnych, literatury międzytestamentalnej i wybranych tekstów Ojców Kościoła, zob. A. T r o n i n a, Jozue -Jezus. Biblijna typologia Zbawiciela, Verbum Vitae 1/2002, s. 41-56; autor poświęca komentarzowi Orygenesa s. 53-54.

2 Monografia poświęcona orygenesowskiej interpretacji Księgi Jozuego, zob. M. M a r it a n o, E. d a I C o v o I o (red.), Omelie su Giosuè. Lettura origeniana, Nuova Biblioteca di Scienze Religiose 5, Roma 2007.

3 Sam Hieronim we wcześniejszych pismach używa Jesus Nave, a dopiero w późniejszych Josue. W Listach 22 (22,19; PL 22,406; z 384 r.), 39 (39,3; PL 22,470; z 384 r.) i 108 (108,11; PL 22,886; z 404 r.) posługuje się zwrotem Jesus Nave, natomiast w Liście 129 (129,5; PL 22,1105 z 414 r.) już czytamy Josue. W najpóźniejszych komentarzach (zwłaszcza do Księgi Ezechiela, z 414 r.) posługuje się wyłącznie Josue. Po Hieronimie niektórzy pisarze używają 
U Orygenesa odniesienie chrystologiczne postaci Jozuego rozpoczyna się już Wj 17,8-13, gdzie znajdujemy opis bitwy Izraelitów z Amalekitami. Jozue na polecenie Mojżesza toczy walkę z wrogami Izraela, co zapowiada walkę Jezusa z szatanem na krzyżu. Motyw krzyża na górze Golgoty zostaje podkreślony przez gest uniesionych rąk Mojżesza: dopóki trzyma je wzniesione - jak ręce Jezusa na krzy$\dot{z} u$ - dopóty Izrael odnosi zwycięstwo. ${ }^{4}$

Śmierć Mojżesza i przejęcie władzy nad Izraelem przez Jozuego (Joz 1,2) obrazują przełom w historii zbawienia, jaki dokonał się wraz z przyjściem na świat Jezusa. Dawna ekonomia zbawienia, którą symbolizuje Mojżesz, zostaje zastąpiona nową, zobrazowaną przez Jozuego. Umiera stare Prawo, by w jego miejsce nastało nowe, Jezus zajmuje miejsce Mojżesza i obejmuje zwierzchnictwo nad Ludem Bożym. ${ }^{5}$

Jozue wprowadza Izraela przez Jordan do Ziemi Obiecanej (Joz 1,3: „Każde miejsce, na które wstąpicie śladami stóp waszych, dam wam"). Według Orygenesa, jest to zapowiedź daru ziemi, o której czytamy w Mt 5,5: „Błogosławieni cisi, albowiem oni na własność posiądą ziemię". Ziemia, do której wprowadza Chrystus, została odebrana szatanowi (ludy zamieszkujące Kanaan symbolizują demony ${ }^{6}$ ) i jest duchowym miejscem w bliskości Zbawiciela.?

Szczególnie interesująca z punktu widzenia hermeneutyki biblijnej jest następująca interpretacja Orygenesa: „Jeśli zaś zdołasz od litery wznieść się ku duchowi i od sensu historycznego wstąpić w górę ku wyższemu sensowi, wtedy naprawdę wstąpiłeś na wysokie i wyniosłe miejsce, które otrzymasz w dziedzictwie od Boga. Jeśli bowiem rozumiesz, że w Pismach są symbole, jeśli dostrzegasz, że są tam figury spraw niebieskich, jeśli umysłem i rozumem szukasz tego, co w górze, gdzie przebywa Chrystus, zasiadając po prawicy Boga (Kol

jeszcze zwrotu Jesus Nave, np. Jan Kasjan (†435), Kasjodor (†580), Izydor z Sewilli (†636). U Gregorza Wielkiego (†604) spotykamy już wylącznie imię Josue. Od VII w. zasadniczo przyjmuje się określenie Josue, aczkolwiek ze względu na odwolania do literatury przed-Hieronimowej (głównie Ambrożego i Augustyna, którzy korzystali z Vetus Latina), gdzieniegdzie spotkamy zwrot Jesus Nave.

${ }^{4}$ O r y g e n e s, In librum Iesu Nave homiliae, 1,3; PSP 34/2, tłum. S. K a I i n k o w s k i, Warszawa 1986, s. 6.

s Tamze, 2,1; s.12.

- Tamże, 1,6; s.10.

7 „Jeśli przeto wiarą życiem, czystością i cnotą dotrzesz aż do Chrystusa zasiadającego po prawicy Boga oraz ... wstąpisz na to miejsce, to Bóg ci je da; a wówczas staniesz się nie tylko dziedzicem Boga, lecz również współdziedzicem Chrystusa"; tamże, 2,3; s.14. 
3,1), wówczas i to miejsce otrzymasz na własność ". ${ }^{8}$ Zatem Orygenes kreśli przed nami perspektywę duchowego podboju, który wyraża się w zdobywaniu nowych obszarów sensu biblijnego. Pozostając na płaszczyźnie znaczenia literalnego, nie postawiliśmy jeszcze naszych stóp na Ziemi Obiecanej. Dopiero w miarę docierania do duchowych znaczeń, podbijamy hermeneutyczny Kanaan. Dokonuje się to dzięki wysiłkowi umysłu i rozumu (,jeśli umysłem i rozumem szukasz”), będąc równocześnie darem od Boga („wówczas i to miejsce otrzymasz na własność"), gdyż duchowe rozumienie Biblii Orygenes postrzega jako równoczesne obdarowanie Boże i ludzki wysiłek.

\section{Zwiadowcy u nierządnicy Rahab}

Epizod dotyczący zwiadowców przybyłych do Jerycha i przyjętych przez nierządnicę Rahab zyskuje u Orygenesa dwojaką interpretację. W kluczu moralnym Rahab symbolizuje duszę każdego człowieka, który jest grzesznikiem, ${ }^{9}$ natomiast zwiadowcami są aniołowie, których Bóg posyła przed sobą, by przygotowali mu drogę do serca człowieka, zanim przybędzie sam Jezus.

Druga interpretacja ma charakter historiozbawczy. Zwiadowcą, przygotowującym drogę Jezusowi w perspektywie dziejów zbawienia, jest Jan Chrzciciel, natomiast Rahab oznacza „Kościół Chrystusowy, który został zgromadzony z grzeszników jakby z nierządu". ${ }^{10}$

Istotną rolę w opowiadaniu o zwiadowcach pełni purpurowy sznur, będący znakiem wybawienia dla rodziny nierządnicy Rahab (Joz 2,18-21). Symbolika, jaka wyłania się z tego epizodu narracji, obraca się wokół trzech motywów literackich. Pierwszym z nich jest kolor czerwony (purpurowy), który w tradycji wczesnochrześcijańskiej wskazywał na krew Jezusa przelaną na krzyżu. ${ }^{11}$ Drugim motywem implikującym znaczenie symboliczne jest wnętrze domu jako miejsce dające schronienie. Dla Orygenesa oznacza ono Kościół święty, poza

B Tamże.

9 Nierządnicą była również dusza każdego z nas, dopóki żyła w pragnieniach i pożądliwościach cielesnych"; tami̇e, 1,$4 ;$ s. 8.

10 Tamże, 2,4; s. 19.

" „Nie otrzymała innego znaku, tylko purpurowy, symbolizujący krew. Wiedziała bowiem, że nie ma innego ocalenia, jak tylko we krwi Chrystusa"; tamże, 3,5; s.20-21. Podobną symbolikę odczytywano w czerwonej tasiemce na ręce Zeracha $(\operatorname{Rdz} 38,28)$ i w porównaniu ust Oblubienicy do czerwonej wstążki (Pnp 4,3). 
którym nie ma zbawienia. ${ }^{12}$ Trzeci - to okno, z którego zwisa sznur: symbolizuje ono wcielenie Chrystusa. Na pierwszy rzut oka trudno uchwycić sens symbolu, jednak nasz autor stara się go wyjaśnić w swoim komentarzu: „Okno oświetla dom i przez okno otrzymujemy nie pełnię światła, lecz tylko tyle, ile wystarcza naszym oczom i naszemu wzrokowi. Ponieważ więc również wcielenie Chrystusa nie przyniosło nam wyraźnego i pełnego widoku Bóstwa, lecz sprawiło, że przez Jego wcielenie jakby przez okno oglądamy światłość Bóstwa, przeto wydaje mi się, że dlatego znak zbawienia został dany przez okno". ${ }^{13}$

\section{Zdobycie Jerycha}

Kolejnym epizodem, który doczekał się interesującej interpretacji symbolicznej, jest zdobycie Jerycha, a zwłaszcza motyw trąb, których dźwięk spowodował upadek murów miasta: „Lud wzniósł okrzyk wojenny i zagrano na trąbach. Skoro tylko usłyszał lud dźwięk trąb, wzniósł radosny okrzyk wojenny i mury rozpadły się na miejscu" (Joz $6,20)$. Orygenes sugeruje dwie interpretacje symboliczne tego wydarzenia, przy czym w obu Jerycho symbolizuje cały świat. Pierwsza interpretacja ma charakter anagogiczny i dotyczy końca świata. Komentator posiłkuje się cytatem z 1 Tes 4,16, w którym św. Paweł, korzystając $z$ ikonosfery apokaliptyki żydowskiej, również przywołuje motyw trąb. W myśl tej interpretacji, wkroczenie Jozuego do Jerycha obróconego w ruinę zapowiada powtórne przyjście Chrystusa w kontekście apokaliptycznych kataklizmów. ${ }^{14}$ Druga interpretacja, która znalazła licznych kontynuatorów w późniejszej tradycji Kościoła, ${ }^{15}$ odnosi dźwięk trąb do głoszenia Ewangelii, które kruszy „obwaro-

12 „Jeśli ktoś z tego ludu chce się ocalić, niechaj przyjdzie do tego domu, aby mógl osiągnąć zbawienie. Niechaj przyjdzie do tego domu, w którym krew Chrystusa jest znakiem odkupienia ... Poza tym domem, to znaczy poza Kościołem, nikt się nie może zbawić. kto wyjdzie na zewnątrz, sam jest winien swojej śmierci. Tutaj jest znak krwi, bo i tu jest oczyszczenie, które przez krew się dokonuje"; tamie, 3,5; s. 21.

13 Tamże, 3,5; s. 21 . Okno w znaczeniu symbolicznym w odniesieniu do wcielenia Chrystusa odnajdujemy również $w$ interpretacjach sceny przybycia Oblubieńca do domu Oblubienicy (Pnp 2,9).

${ }_{14}$ Tamie, 6,4; s. 36.

is Na temat dalszych dziejów tej interpretacji, m.in. u Izydora z Sewilli, Rabana Maura i Garniera z Langres, zob. K. B a r d s k i, Uczeń Chrystusa - glosiciel Ewangelii. Obrazy biblijne $w$ starożytnych $i$ średniowiecznych interpretacjach, Warszawskie Studia Teologiczne 21/2008, s. 53-55. 
wania, których jak murów używał ten świat, mianowicie: kult demonów, fałszywe wróżby, zmyślenia augurów, haruspików i magów", ${ }^{16}$ a więc religie pogańskie. Tymi, którzy dęli w trąby, byli kapłani, „skoro jednak przyszedł nasz Pan, Jezus Chrystus, którego przyjście symbolizował ów dawny syn Nawego, posłał kapłanów - apostołów swoich, niosących kute trąby, to znaczy wspaniałą i niebiańską naukę swego przepowiadania. ${ }^{17}$ Jednakże, dodaje Orygenes, nie tylko kapłani dęli w trąby, lecz usłyszawszy głos trąb, również lud ,wydał radosny okrzyk". ${ }^{18}$ Ten okrzyk ludu „symbolizuje poczucie zgodności i jednomyślności", ${ }^{19}$ tym samym komentator wyraźnie podkreśla powszechne powołanie chrześcijan do dzieła głoszenia Ewangelii.

\section{Zdobycie Aj}

Również epizod zdobycia miasta $\mathrm{Aj}$ (Joz 8,3-29) doczekał się u Orygenesa dwojakiej interpretacji: eklezjalnej i moralnej. Strategia Jozuego polegała na pozorowanej ucieczce jednej części armii, by sprowokować obrońców miasta do pościgu, podczas gdy druga część armii miała wkroczyć do miasta i zdobyć je. Otóż, dla Orygenesa, wojsko Jozuego symbolizuje Kościół, który składa się z chrześcijan nawróconych $\mathrm{z}$ judaizmu i chrześcijan nawróconych z pogaństwa. $\mathrm{Ci}$ pierwsi są symbolizowani przez połowę armii, która ucieka - w domyśle - „przed obciążeniami i nakazami Prawa” Mojżeszowego. Natomiast druga połowa armii, która zdobywa Aj, symbolizuje chrześcijan nawróconych spośród pogan, gdyż to oni zdobywają miasto szatana oraz osiągają zbawienie, którego nikt by się nie spodziewał. ${ }^{20}$

Interpretacja moralna ogniskuje się na tej części armii, która ucieka przed wrogiem, by umożliwić zwycięstwo. Orygenes stawia pytanie: „Zastanówmy się, czy nie istnieje coś takiego, co możemy pokonać przez ucieczkę i czy ucieczka nie może być cnotą?" ${ }^{21}$ Odpowiedź formułuje, opierając się na Mt 10,23 („,Jeśli was prześladować będą w tym mieście, uciekajcie do innego"), twierdząc, że właśnie ucieczka przed złem i grzechem oznacza duchowe zwycięstwo.

\footnotetext{
16 Orygenes, 7,$1 ;$ s.37.

17 Tamie.

18 Tamie, 7,2; s.28.

19 Tamie.

20 Tamie, 8,2; s. 46.

21 Tamie, 8,6; s. 49.
} 


\section{Duchowy sens wojen toczonych przez Jozuego}

Również pozostałe opisy podbojów Ziemi Obiecanej doczekały się u Orygenesa szczegółowych interpretacji alegorycznych. Zasadniczo jednak możemy wyróżnić trzy rodzaje symbolizacji tych wydarzeń.

Pierwsza postrzega $\mathrm{w}$ mieszkańcach Kanaanu symbol szatana i złych duchów, przeciwko którym walczy Jozue/Chrystus jako wódz Izraela/Kościoła. Syntetycznie Orygenes aktualizuje tę symbolikę w 13 homilii: „Również obecnie Pan mój, Jezus Chrystus, prowadzi walkę przeciwko wrogim mocom. Wypędza je z miast, którymi rządzili, to znaczy z dusz naszych; a czyni tak po to, aby «grzech nie królował w nas dłużej» (Rz 6,12), aby po usunięciu króla grzechu $\mathrm{z}$ miasta naszej duszy stałą się ona miastem Boga ". ${ }^{22}$

Zauważmy, że w powyższej interpretacji kryje się nie tylko odniesienie do demonów, ale również do ludzkiego grzechu. Drugą zatem symboliką jest odczytanie walk z Kananejczykami w kluczu moralnym, jako walki z ludzką słabością i grzesznością. W tym znaczeniu Orygenes interpretuje okulawienie koni wojsk królów, którzy wystąpili przeciw Jozuemu (Joz 11,9): „Uznajemy, że w omawianym tekście konie i rydwany stanowią symbol namiętności cielesnych, takich jak lubieżność, rozpusta, pycha i lekkomyślność”. ${ }^{23}$

Trzecia symbolika kojarzy podbój Kanaanu z dziełem ewangelizacji. Komentując Joz 13,1: („Pozostało jeszcze bardzo wiele ziemi do zdobycia”), Orygenes dokonuje kolejnej aktualizacji tekstu: „Pójdź za mną, słuchaczu, po delikatnych liniach Słowa, a pokażę ci, w jaki sposób powtórnie zdobywa ową ziemię, której wielkie obszary, jak powiedziano Jezusowi [czyli Jozuemu], pozostały jeszcze do zdobycia (...) Jeśli chodzi o nasze czasy, to widzimy, że wiele jeszcze zostało krajów, które nie zostały poddane pod stopy Jezusa, a przecież On wszystkie ziemie musi objąć w posiadanie". ${ }^{24}$

Możemy zatem podsumować, że odniesienie figury Jozuego do Chrystusa kładzie nacisk na trzy główne aspekty typologii: Jezus jest wodzem i zwycięzcą na wzór Jozuego, ponieważ: pokonuje szatana, przejmując jego terytorium; przewodzi w duchowej walce ludu Bożego z grzechem, egoizmem i pychą; w końcu jest też zdobywcą, który dzięki głoszeniu Ewangelii staje się Panem ludzkich serc.

ks. Krzysztof BARDSKI

22 Tamíe, 13,1; s. 73.

23 Tamie, 15,3; s. 84.

${ }^{24}$ Tamìe, 16,3; s. 93-94. 